\title{
An interview with Angela Nieto
}

Angela Nieto is Full Professor at the Instituto de Neurociencias (CSIC-UMH) in Alicante, Spain, and Head of the institute's Developmental Neurobiology Unit. She is also the current president of the Spanish Society for Developmental Biology (Sociedad Española de Biología del Desarollo, SEBD). We interviewed her to talk about the plans of the SEBD for the coming years.

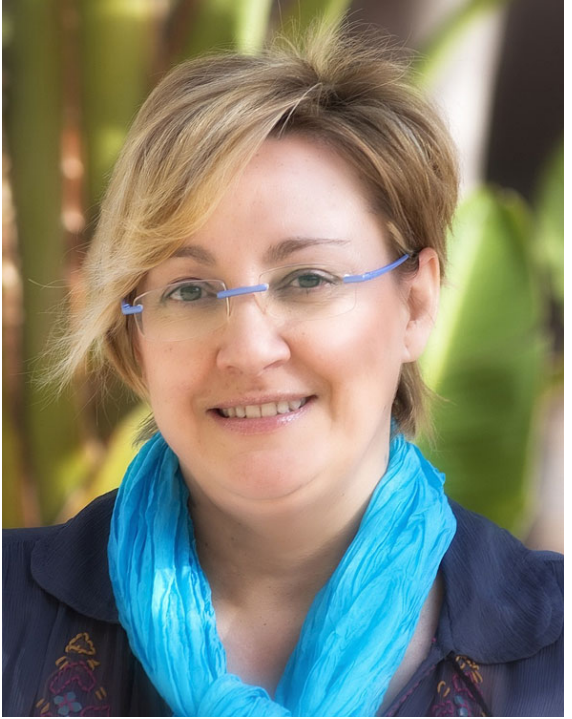

What research topics are you working on?

We have been working on the mechanisms that drive cell movements early in development. More than 20 years ago we started to work on the Snail family of transcription factors and found that, in vertebrates, Snail factors are very important for the triggering of the epithelial-tomesenchymal transition (EMT) in the embryo. Therefore, Snail factors are necessary for cell delamination at the primitive streak and at the neural crest, as well as in other tissues. Essentially, the EMT has kept us very busy for many years now. Over the years we have extended our analysis to not only study the EMT during embryonic development, but also in pathology - particularly in tumour progression and in other diseases that involve the EMT. We also extended our research into the role of Snail to EMTindependent processes, such as bone growth and homeostasis, and started investigating some other EMT inducers.

\section{Interview by Eva Amsen*}

Online editor, Development

*Author for correspondence (e.amsen@biologists.com)

\section{You're the president of the Spanish Society for Developmental Biology. How long have you held this position?}

I've been president for a year now, and it has been quite a busy year, because we are revitalizing the society at the moment. For example, we have written new statutes to accommodate the society to new regulations.

\section{How was the SEBD originally formed?}

The society was initiated in 1994, in association with the International Journal of Developmental Biology (IJDB). Juan Aréchaga, of the University of the Basque Country, is the Editor in Chief of the IJDB and put a lot of effort into the journal. At the same time it was important to have Antonio Garcia-Bellido, one of the main figures in developmental biology in Spain, working together with Juan Aréchaga to create the society. At the moment, the links with the journal are still tight, but the society has become more independent.

\section{How often does the SEBD organize meetings for its members?}

The first meeting was held in 1996, in Bilbao. From then on we've had meetings every 2 years, and we will continue to do that. We're also interested in interacting more with other developmental biology societies, so we often organize joint meetings. We have done this already with the British, Portuguese and French societies for developmental biology, and at our next meeting in November - again held in association with the Portuguese society - we will have the North American Society for Developmental Biology as an invited guest. We are very close to the Portuguese society and have plans for a long-term association, so that we can perhaps have meetings every year: one year in Spain and the next year in Portugal.

The Ministry of Science and
Innovation has been
discontinued, and
investment in research and
development will be
reduced in Spain

\section{What would you like to see the society achieve in the near future?}

We want to promote the various activities of the society. Notably, we are trying to increase the interactions among the members and strengthen our ties with other European societies. But at the same time we have two additional aims. One is to encourage young scientists to be interested in developmental biology. The second is to increase the visibility of the SEBD and of scientific research in general to Spanish society. In Spain, there is not much of a tradition of explaining science to lay people. However, we know that people in Spain are extremely interested in science and scientists. To give you an idea, some recent statistics showed that when you ask laypeople their opinion on different professions, scientists come out very high. The Spanish public really appreciates what scientists do and they trust scientists very much. This is very nice, and it serves as a strong message that we have to communicate the research we do, and that we should be able to provide the public with an informed opinion on several issues related to developmental biology, including those linked to bioethical issues. As a scientific society, we may have to work together with the mass media. That is something that I think hasn't been done properly in the past, but which the public is actually asking us to do.

\section{What are the current challenges for researchers in Spain?}

Undoubtedly, one of the challenges is the economic crisis, which not only affects Spanish science, but also science in the rest 
of Europe and all over the world. At the start of this year, we received bad news, as the Ministry of Science and Innovation has been discontinued, and investment in research and development will be reduced in Spain, which is very disappointing. Securing funds for research may also be related to scientific outreach and keeping the public informed: if society believes that investing in research is crucial, then it will be easier to convince politicians that research should be protected and that cutting down the budget for science means cutting down our progress and our future.

\section{How can Spanish developmental biologists play a role in this?}

It is now easier than ever to promote translational research and, as developmental biologists, many of us have connections with biomedicine. But we have to firmly support investment in basic research. We have to convey the message to the public that we really need to know the physiology of the biological processes before we can design intelligent strategies for therapies.

\section{The message we hope to pass on during school visits: science is fun and...essential for our future}

\section{Does the SEBD have any concrete plans for providing public outreach?}

In this first year of the new society committee we've been busy trying to generate all the instruments that we actually need to carry out our activities. We have a new webpage (www.sebd.es) and we're preparing a lot of different activities to promote visibility and interactions - those will be launched this year. We would like to promote not just developmental biology but scientific research in general. Not only at universities, to try to attract $\mathrm{PhD}$ students, but also by going to schools to show kids how much fun it is to work in science. Scientific research takes a lot of effort, and although sometimes it's disappointing because experiments don't always work, it is very exciting and it is always different. That is the message we hope to pass on during school visits: science is fun and, very importantly, essential for our future. 